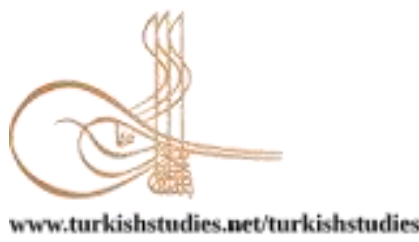

Turkish Studies

\title{
Bir Tarih Kaynağı Olarak Kur’an'da “Fi Sebîlillah” Kavramı ve Tarihi Çerçevesi
}

\author{
As a Source of History the Term "Fi Sebilillah" and Its Historical Frame in the Quran
}

\author{
Mehmet Çakırtaş*
}

\begin{abstract}
The struggle of the Prophet and the believers for the sake of Islam is adjectived "fi sabilillah" in the Quran. This phrase, which is widely used in Islamic historical sources, describes the basic characteristics of Muslims' relations with non-Muslims. This situation had a significant impact on the Islamic sources as well as the thought of the first Muslims. In this article, the reflections of the concept of "fi sabilillah" in sirah, starting from the Quran, which is one of the main sources of sirah, has been investigated. Studies on the term fi sabilillah, especially in the field of tafsir and fiqh, have been conducted. However, as far as we can determine, this issue has not been handled in terms of sirah. In the research, firstly the verses about "fi sabilillah" in the Quran were determined. Eleven different concepts and words are used together with the term "fi sabilillah". It has been seen that these concepts and words can be reduced to four titles and titled. As a result of the research, it was seen that the term "fi sabilillah" is oriented towards war, such as jihad, gazve, and seriyya, and has features that give direction relations with non-Muslims. This term also determined the principles of the behavior of Muslims. In the study, it has been observed that Muslims' donation as a method of creating financial resources against the enemy is explained with the term fi sabilillah. The term "fî̀ sabilillah" describes the value of every effort in these processes.
\end{abstract}

Structured Abstract: One of the basic terms of the Quran as a source of Sirah is the term "fi sabilillah", which means "in the way of Allah". This expression, which is widely used in the Qur'an, describes the qualities of Muslims that reveal their relations with non-Muslims. The term "fi sabilillah" has been reflected in all sources of Sirah, from hadith literature to biographical works on the life of the Prophet. Some studies have been done on the Fiqh and Tafsir aspects of the term, but the Sirah reflections of the subject have not been studied as far as we can detect. In this article, it has been tried to determine the reflections of the term "fi sabilillah" in Sirah, based on the Quran. In the research, first of all, the verses about "fi sabilillah" in the Quran were determined. Eleven different concepts and words are used together with the term "fi sabilillah". It has been observed that this term and words can be reduced to four titles.

In the first years of the Prophet's declaration of Prophethood, a policy of violence against particularly weak Muslims was implemented by the Makkan polytheists. This process led to the migration to Medina and the military struggle there. In the Qur'an, the patience and efforts of Muslims against the calamities they suffer in the way of Allah are valued. The persecution faced by Muslims has been made valuable with the term "fi sabilillah". This usage, points to the rewards of all believers, men and women, who faced persecution in the

\footnotetext{
* Dr, Daire Başkanı, Radyo ve Televizyon Üst Kurulu (RTÜK)

Dr., Head of Department, Radio and Television Supreme Council

ORCID 0000-0002-2221-1509

m_cakirtas@hotmail.com

Cite as/ Atıf: Çakırtaş, M. (2021). Bir tarih kaynağı olarak Kur'an'da “Fi Sebîlillah” kavramı ve tarihi çerçevesi. Turkish Studies, 16(2), 583-595. https://dx.doi.org/10.7827/TurkishStudies.49045

Received/Geliş: 26 January/Ocak 2021

Accepted/Kabul: 25 April/Nisan 2021

Checked by plagiarism software

Published/Yayın: 30 April/Nisan 2021

CC BY-NC 4.0
} 
way of Allah. Of course, it is seen that the troubles such as fatigue, hunger and thirst encountered during jihad are evaluated in this context.

One of the contexts in which the term fi sabilillah is used is hijrah. The issues related to this incident, which constitutes one of the turning points of Islamic History, were reflected in the Quran. Deciding to migrate is a great sacrifice for believers. Therefore, most of the verses are for those who migrate and it is emphasized that the Hijrah is a duty first. Thus, migration was encouraged. The term "fi sabilillah" is reflected in Sirah sources in the context of the Tabuk expedition, Abu Bakr's swearing not to help the immigrant Mistah because of his role in the "ifk" event, and the allocation of "fay" revenues to immigrants.

The most common use of the term "fi sabilillah" in Sirah sources is its use with "jihad" and "qatl". The use of the term jihad together with the term fi sabilillah reveals the framework of meaning of jihad. There are efforts within this framework that God will be pleased with. However, most of its use in Sirah is associated with gazves and seriyyes. One of the prominent term associated with jihad is "qital", which means war. Q1tal refers to the part of jihad for actual war. It is necessary to respond to those who fight, without exceeding the limits. The definition of Muslims killed while fighting in the way of Allah as "those killed in the way of Allah" is another use of the term fi sabilillah. It was used especially for believers who were martyred after the Battle of Uhud. In the context of expressing the processes of setting out for war in the way of Allah, the terms "darb" and "nefr" were also used with the term fi sabilillah. It was emphasized that one should be careful about the people who will be encountered on the road for war. The situation of Amir b. al-Ezbat, who was mistakenly killed in such an expedition, was reflected in the Sirah sources.

It is seen that the concept of fi sabilillah has a wide meaning in Sirah. It is possible to witness the use of the term fi sabilillah in many events during the Medina period. The seriyye of Abdullah b. Jahsh and the war of Uhud can be mentioned in this context. In the Quran, the value of jihad in the way of Allah is pointed out when the polytheists performed their Kaaba services as a means of pride. The reflections of the term "qital" in Sirah were in the context of the Battle of Badr and the siege of Benî Kaynukā' Jews.

In the study where the contexts of the term fi sabilillah are discussed, the last item is the use of infaq fî sabilillah. In the verses, the method of infaq, the encouragement to make and the reward of those who donate are mentioned. The term "infak fî sebîlillah" has come to the fore as an important institution to meet the expenses of gazves and seriyyes. As reflected in the Sirah sources, it is seen that the term infaq fî sebîlillah is used to help believers who do not have the means of the Umrah al-Qada.

As a result, it is understood that the term "fi sabilillah", which is one of the basic terms of the Quran, has a wide area of use in the Quran as a source of history. The main subjects of the verses in which the concept is mentioned are the main subjects of Islam such as religion, faith, obedience, deeds, hijrah, jihad, infaq, martyrdom and morality. The reflections of the term "fi sabilillah", which is all associated with the Medinan period, on the Sirah sources influenced the understanding of the verses.

Keywords: History of Islam, sirah, "fî̀ sabilillah", jihad, qital.

Öz: Hz. Peygamber'in ve ona inanan müminlerin İslamı yaşama ve tebliği uğrunda verdikleri her türlü mücadele, Kur'an-1 Kerim'de “fî sebîlillah” tabiri ile sıfatlandırılmıştır. Diğer temel kaynaklarda olduğu gibi İslam tarihi kaynaklarında da yaygın bir şekilde kullanılan bu ifade, daha ziyade Müslümanların Müslüman olmayanlarla ilişkilerindeki temel nitelikleri tanımlamıştır. Bu durum siyer kaynaklarına da önemli ölçüde yansımış, ayrıca ilk Müslümanların düşünce dünyasını etkilemiştir. Bu makalede, siyerin temel kaynaklarından biri olan Kur'an-1 Kerim'den hareketle "fî̀ sebîlillah” kavramının siyerdeki yansımaları araştırılmıştır. "Fî sebîlillah" ifadesi üzerine, özellikle tefsir ve fikıh alanında yoğunlaşan çeşitli çalışmalar yapılmıştır. Ancak tespit edilebildiği kadarıyla konu siyer açısından ele alınmamıştır. Araştırmada öncelikle Kur'an'daki “fî sebîlillah" tabirinin yer aldığ 1 ayetler tespit edilmiştir. Tekikler neticesinde on bir ayrı kavram ve kelimenin, "fî sebîlillah" tabiri ile birlikte kullanıldığı belirlenmiştir. Bu kavram ve kelimelerin dört ana konuya indirgenebileceği anlaşılmış ve bu şekilde başlıklandırılmıştır. Araştırma neticesinde "fî̀ sebîlillah" tabirinin cihad, gazve ve seriyye gibi savaşa dönük yönlerinin olduğu gibi Müslümanların gayrimüslimlerle ilişkilerine istikamet veren niteliklerinin de olduğu görülmüştür. Bu tabir aynı zamanda Müslümanların davranışlarının ilkelerini de ortaya koymuştur. Çalışmada, Müslümanların düşmana karşı mali kaynak oluşturmada bir yöntem 
olarak infakta bulunmalarının "fi sebîlillah" tabiri ile teşvik edildiği görülmüştür. Bu süreçlerdeki her türlü çabanın kıymetini "fî̀ sebîlillah" tabiri nitelemiştir.

Anahtar Kelimeler: İslam tarihi, siyer, "fî sebîlillah”, cihad, kıtal

\section{Giriş}

Bir siyer kaynağ 1 olarak Kur'an-1 Kerim'de, fiillerin kıymetini ortaya koyan önemli kavramlardan biri "Allah yolunda" anlamına gelen (Fîrûzâbâdî, 1986, s. 403; Mustafa, Zeyyâd, Abdulkâdir, vd., 1992, s. 415; Zemahşerî, 2016, s. 634-636) "fî̀ sebîlillah" tabiridir. İnsanların yararına olan ve bireysel çıkarların öncelenmediği davranışlar genelde bu minvalde değerlendirilmiştir (Mustafa vd., 1992, s. 415; Köse, 2004, s. 108).

Kur'an'ın temel kavramlarından biri olan "fî̀ sebîlillah", hadis edebiyatından Hz. Peygamber'in hayatını konu edinen biyografi eserlerine kadar bütün siyer kaynaklarına yansımıştır. Kavramın fikıh (Köse, 2004; Aktaş, 2015; Albayrak, 2013) ve tefsir (Elik, 2006; Yıldız, 2015; Dinçoğlu, 2015) alanındaki yeri ve önemi, makaleler ve tezler üzerinden çalışılmıştır. Ancak konunun İslam tarihi ve siyere yansımaları tespit edilebildiği kadarıyla incelenmemiştir. Konu, özellikle "sebîl" kavramından hareketle bir kitap çalışmasını fazlasıyla hak etmektedir.

Bu makalede, "fî̀ sebîlillah" kavramı, siyerle ilişkileri bakımından ele alınmıştır. Kur'an açısından tespitlerle başlayıp, hadis literatürü ve nihayet siyerdeki yansımalar araştırılmıştır. Ayetlerin ilişkili olduğu tarihsel arka plan siyer kaynaklarından teyit edilmeye çalışılmıştır.

Araştırma neticesinde, "fî̀ sebîlillah" kavramının Müslümanların Müslüman olmayanlarla ilişkilerinin muhtelif boyutları ile yakından ilişkili olduğu görülmüştür. Gazve ve seriyyeler bu meyanda ifade edilebilecek en önemli başlıklardır. Hicret, infak, cihad gibi fedakârlık gerektiren çabalar ve bunlarla birlikte çekilen eziyetler "fî̀ sebîlillah" kavramıyla sıfatlandırılmıştır.

\section{Fî Sebîlillah Kavramı}

"Fî sebîlillah" kavramı, Arapça "fî" harf-i ceri ile yol anlamına gelen "sebîll" kelimesinin (İbn Manzur, 1999, s. 163) Allah lafzına nispet edilmesiyle yaygın bir kullanım olarak Kur'an'da yerini almıştır. Sebîl kelimesi, aynı zamanda çıkış yeri ve delil anlamlarına gelmekle birlikte (Mustafa vd., 1992, s. 415) Kur'an'da din, (Kur'an-1 Kerim 3/99) Allah'a itaat, (Kur'an-1 Kerim 2/190) güç kuvvet, (Kur'an-1 Kerim 3/97) çıkış yolu, (Kur'an-1 Kerim 4/15) davranış ve alışkanlık (Kur'an-1 Kerim 4/22) gibi değișik anlamlarda kullanılmıştır. Kavram olarak "sebîl", "peygamberlerin insanları davet ettiği Allah'ın dininin adı" şeklinde de tanımlanmıştır (Kur'an-1 Kerim 40/7; 14/12; 13/33).

"Fî sebîlillah" tabirinin harf-i cerden sonraki ikinci kısmını oluşturan sebîlullah tamlaması, Allah'ın yapılmasını emrettiği iyi işler için kullanılmıştır (Mustafa vd., 1992, s. 415). Tamlamanın Kur'an'da farklı harf-i cerler ile de kullanımları mevcuttur. Ancak makalenin çerçevesini taşmaması için bu çalışmanın dışında tutulmuştur.

"Fî sebîlillah" tabiri Kur'an'da yaklașık 50 yerde geçmektedir. Bunların beșinde Allah lafzı yerine zamir kullanılmıştır. İkisi, "ya-i mütekellim" ile üçü ise "hu" zamiri ile yer almıştır. Sebîlullah ifadesi, Mekkî ayetlerde genel olarak Allah'a, ahiret gününe ve Peygambere iman ile tevhit gibi itikadî konularla ilgilidir (Kur'an-1 Kerim 2/154; 3/146; 4/74; 8/ 60). Medenî ayetlerde ise hicret, (Kur'an-1 Kerim 2/218; 4/89; 8/72, 74; 9/20, 34; 22/58), cihad, (Kur'an-1 Kerim 2/218; 5/35, 54; 9/19, 20; 9/24, 41; 49/15; 61/11) savaş, mücadele (Kur'an-1 Kerim 2/190, 244, 246; 3/13, 167; 4/74, 75,$84 ; 9 / 111 ; 73 / 20$ ) ve bunlarla bağlant1lı olarak zekât, infak, (Kur'an-1 Kerim 2/195, 261; 8/60, 72, 74; 47/38; 57/10) Allah yolunda harcamak, Allah'a itaat (Kur'an-1 Kerim 2/195, 261; 4/ 76) ve dinin kurallarını yaşamak anlamlarında kullanılmıştır. "Fî sebîlillâh" kavramının geçtiği ayetlerin 
tamamı Medine'de nazil olmuştur. Mekke'de nazil olanlar ise " $\mathrm{f}$ " "yerine "an" harf-i ceriyle yer almıştır (Kur'an-1 Kerim 6/116; 7/45, 86; 11/19; 38/26).

Tespit edilebildiği kadarıyla “fî̀ sebîlillah” kavramı Kur'an’da, Müslümanların, gayrimüslimlerle mücadeleri bağlamında hicret, cihad ve infak gibi fiillerin değerini ortaya koyan ayetlerde geçmektedir.

\section{Fî Sebîlillah Kavramının Siyerdeki Yansımaları}

\section{1. Eziyet ve Musibet}

Kur'an'ın inmeye başlaması ve Hz. Peygamber'in İslam davetini ortaya koymasından sonraki süreçlerde farklı tepkilerle karşılaşılmıştır. Başlangıçta sakin bir dönem yaşanmış olmasına karşın, inananların sayısı arttıkça Mekkeli müşriklerce, özellikle Müslümanların zayıflarına yönelik bir şiddet politikası yürütülmüştür. Bu sıkıntılı durum, Medine'ye hicreti ve oradaki askeri mücadeleyi doğurmuştur (Acar, 2014a, s. 45). Mekke döneminde Müslümanların karşılaştığ1 muamele, cahiliyenin geleneksel hukuku açısından da bir savaş sebebidir (Acar, 2014b, s. 93-114).

Kur'an'da, Müslümanların Allah yolundaki çabaları değerli görülüp, gösterilen sabır ve gayret için vaatlerde bulunulmuştur. $\mathrm{Bu}$ süreçlerde karş1laş1lan durumlar, genelde Allah yolunda musibete uğramak (Kur'an-1 Kerim 3/146; 9/120) ve Allah yolunda eziyet çekmek (Kur'an-1 Kerim 3/195) şeklinde izah edilmiştir.

Müslümanların karşılaştıkları eziyetler "fî̀ sebîlillah" tabiri ile kıymetlendirilmiştir. Eziyetin “fî̀ sebîlillah” kavramı ile kullanımı, Kur'an'da Âli İmrân 195. ayette yer almıştır. Allah yolunda karşılaşan eziyet için kadın-erkek tüm müminlerin mükâfatlarına işaret edilmiştir ki, ayetin bağlamında hicret, cihad ve kıtal kavramları da mevcuttur. Mekke dönemi ilişkilerinde eziyet, Müslümanlar için daha yoğun şekilde vâki olmuştur. Varaka b. Nevfel, bu hususlara dair öngörülerini Hz. Peygamber'e, "eziyete uğrayacaksın" sözleriyle dile getirmiştir. (İbn Hişâm, 1992a, s. 240). Hatta müşriklerin eziyetleri siyer kitaplarında müstakil başlıklarla konu edilmiştir (İbn Hişâm, 1992, s. 317).

Allah yolunda eziyet ve musibete uğramakla ilgili ayetler, genelde Medine dönemi ile ilişkilendirilmiştir. Ancak ayetlerin anlam alanlarının Mekke dönemiyle de ilgisi vardır. Zira karşılaşılan eziyetlerin çoğu benzerlik göstermektedir. Hz. Peygamber, Mekke'de hapsedilmiş olan Ayyaş b. Rebia ve Hişâm b. As'ı kurtarmak üzere Velid b. Velid'i göndermişti. O da kurtarma çabasında iken ayağı kayıp parmağından yaralandığında bu yaşadığı musibeti, "fî sebîlillah" kavramını kullanarak Allah yolunda karşılaşılan bir durum olarak değerlendirmiştir (İbn Hişâm, 1992a, s. 476). Cihad ederken karşılaşlan yorgunluk, açlık, susuzluk gibi musibetlerin de bu bağlamda değerlendirildiği görülmektedir. Uhud Gazvesi ile ilişkilendirilen musibet de böyledir (Kur'an-1 Kerim 9/120; Vâkıdî, 1989a, s. 322; İbn Hişâm, 1992c, s. 88). Bu ayetlerin Müslümanların karşılaştıkları musibetlere karşı bir destek olduğu anlaşılmaktadır.

Kur'an, Allah yolunda maruz kalınacak sıkıntılar ve başa geleceklerden ötürü sabretmek gerektiğini ve bu uğurda çekilenlerin karşılıksız kalmayacağını teminat altına almıştır (Kur'an-1 Kerim 3/146; 9/120). Bu durum "isabe fi sebîlillah" (آصَابَ في سَبِيلِ اللَّ) kavramıyla açıklanmıştır. "İsabe fi sebîlillah" Allah yolunda bir şeye maruz kalmak, başına bir şey gelmek anlamlarında kullanılmıştır. Kur'an'da iki ayette geçmektedir (Kur'an-1 Kerim 3/146; 9/120). Medine'de inen bu ayetlerde, Allah için çekilen sıkıntılara sabretmek ve bunun karşılığında kazanılacak mükâfat konu edilmiştir. Ayrıca Medine ve çevresindeki halkların Hz. Peygamber ile birlikte olmalarının ve onunla beraber cihad etmelerinin gerekliliği üzerinde durulmuş, Allah yolunda susuzluk, yorgunluk ve açlığa maruz kalmalarının karşılıksız kalmayacağı taahhüt edilmiştir.

Siyerde “Allah yolunda musibete uğramak” tabiri özellikle Uhud gazvesi bağlamında sıkça kullanılmıştır (Vâkıdî, 1989a, s. 322; İbn Hişâm, 1992c, s. 88). İlgili ayet (Kur’an-1 Kerim 3/146) de 
Müslümanların manevi yönden desteklenmesi için nazil olmuştur. Savaş esnasında, Hz. Peygamber'in öldürüldüğü haberi yayılmış, bunun üzerine Müslümanlar dağılma tehlikesi geçirmişler (İbn Hişâm, 1992c, s. 88), hatta savaş alanını terk edenler olmuştu. Kur'an bu ayetle, önceki peygamberler ve onların arkadaşlarının bu tür durumlarda maruz kaldıkları her türlü sıkıntıya sabredip sebat gösterdiklerini, Hz. Peygamber'in ashabından da aynı şeyin beklendiğini vurgulamıştır. İbn Hişam'ın, İbn İshak'tan naklettiğine göre geçmiş peygamberlerden düşmanları tarafından öldürülenler de olmuştur. Ancak onların arkadaşları Hz. Muhammed'in ashabının yaptıkları gibi dağılmayıp sebat göstermişler, Allah da mükâfat olarak dünyada düşmanlarını mağlup etmiş, ahirette de sevabını vermiştir (Vâkıdî, 1989a, s. 322; İbn Hişâm, 1992c, s. 89).

\section{2. Hicret}

"Fî sebîlillah" tabirinin Kur'an ve siyerde kullanıldığı bağlamlardan biri de hicrettir. İslam tarihinin dönüm noktalarından birini teşkil eden bu hadiseye ilişkin hususlar, doğal olarak Kur'an'a yansımıştır. 24 ayette hicret ve muhacirlerden bahsedilmektedir. Kur'an'da, önceki peygamberlerin yurtlarından çıkarılmaları ve hicretleri (Kur'an-1 Kerim 29/26) ile Hz. Peygamber ve müminlerin hicretlerine dair ayetler yer almıştır.

Hicrete karar vermek müminler için büyük fedakârlık gerektirmesi nedeniyle zor bir süreç olmuştur. Bununla birlikte, "fi sebîlillah" kavramının geçtiği hicretle ilgili ayetlerin çoğu hicret olgusundan ziyade, hicret edenlere yönelik olmuştur. Hicretin bir vazife olduğu dolaylı olarak tespit edilmiştir (Kur'an-1 Kerim 4/89; 8/72). Ardından hicret edenlerin kıymeti ve onlara verilen mükâfat zikredilmiştir (Kur'an-1 Kerim 9/100). Bu ayetlerde, muhacirlerin sevilmesi (Kur'an-1 Kerim 59/9), onların Allah'ın rahmetine ulaşabilecek olmaları (Kur'an-1 Kerim 2/218; Kur'an-1 Kerim 16/110), günahlarının bağışlanması (Kur'an-ı Kerim 3/195), cennet nimetlerine erişecek olmaları (Kur'an-1 Kerim 16/41) ve en güzel şekilde rızıklandırılmaları (Kur'an-1 Kerim 22/58) gibi konular işlenmiştir. Böylece hicret teşvik edilmiş, hicret etmeyenlerin durumu ile hicret edenlerler arasındaki ilişkilerin şekli ortaya konmuştur. Öncelikle muhacirlerle geride kalanlar arasındaki bağların kesildiği hüküm olarak konulmuştur (Kur'an-1 Kerim 4/89; 8/72). İman edip hicret edemeyenlere, arada antlaşma bulunan bir topluluğa karşı olmamak üzere yardım etmek mümkün kılınmıştır (Kur’an-1 Kerim 8/72). Muhacirler ve Ensar ise bütünün parçalarıdır (Kur'an-1 Kerim 8/74-75). Ensar muhacirlere destek olmaları vesilesiyle ayrıca takdir edilmiştir (Kur'an-1 Kerim 8/74). Hicret etmeyenler şiddetle eleştirilmiş ve hicret etmemeleri nedeniyle içinde bulundukları durumlar göz önüne serilmiştir (Kur'an-1 Kerim 4/97, 100). Kur'an'da konular işlenirken hicret, kimi ayetlerde iman, cihad ve kıtal kelimeleriyle birlikte "fî̀ sebîlillah" kavramı eşliğinde yer almıştır. (Kur'an-1 Kerim 3/195; 8/72; 9/20; 16/110; 22/58). Fî sebîlillah kavramı ayrıca, Hz. Peygamber'in nikâhlaması helal olan kişiler (Kur'an-1 Kerim 33/50), muhacir kadınlardan biat alınmas1 (Kur'an-1 Kerim 60/10), akrabalar arasındaki hukukun hicretin önüne alınması (Kur'an-1 Kerim 33/6) ve fey gelirlerinin muhacirlere tahsisi (Kur'an-1 Kerim 59/8) ile muhacirlerin bazı hatalarından dolayı onlara yardım etmekten imtina edilmemesi (Kur'an-1 Kerim 24/22) bağlamında zikredilmiştir.

Hicretin "fi sebîlillah" kavramıyla kullanımı, tespit edilebildiği kadarıyla siyere üç hadisede yansımıştır. Bunlar, Abdullah b. Cahş seriyyesi ve sonrasında gelişen olaylar, Beni Nadîr seferi sonrasında elde edilen gelirler ve Hz. Ebû Bekir'in muhacir Mistah'a yardımı kesmesi hadisedir. Erken dönemde Müslüman olanlardan olan Abdullah b. Cahş, Habeşistan hicretine katılmış, aynı şekilde Medine hicretinde ailesi ile birlikte yer almıştı. Komutan olarak yer aldığı Batn-1 Nahle diye de bilinen ve kendi adıyla anılan istihbari bir seriyyede, haram aylar içinde iken takip altında tuttuğu kervan lideri Amr b. Hadramî öldürülmüş, kervan ganimet olarak Medine'ye getirilmişti. Allah Resulü, haram ayda yaşanan bu hadise ile elde edilen ganimetleri kabul etmemiş ve Abdullah b. Cahş'a da kendisinin böyle bir şeyi emretmediğini ifade etimişti. Ancak Bakara Suresi 217. ayet ile ilk defa alınan bu ganimetler helal sayılmış ve müşriklerin Müslümanlara reva gördüğü hususlara atıfta bulunulmuştur. Böylece durumları açığa kavuşan Abdullah b. Cahş ve arkadaşları Hz. 
Peygamber'e, katıldıkları bu seriyye nedeniyle bir ecir ve sevap alıp almayacaklarını sormuşlardı. $\mathrm{Bu}$ ayetle Allah yolunda hicret eden ve cihad edenlerin Allah'1n rahmetini umabilecekleri teyid edilmiştir. (İbn Hişâm, 1992b, s. 547; Çakan, İ. L. 1988, s. 88-90).

Hicret ve "fi sebîlillah" kavramının siyere yansıdığı bir diğer olay ise Benî Nadîr Yahudilerinin sürgünü sonrası geriye kalan mallarının taksimi bağlamında söz konusu olmuştur. Hicretin dördüncü yılında Nadîr oğulları, Hz. Peygamber ile yapmış oldukları anlaşmaya sadakatsizlik gösterip onu öldürmek istemişlerdi. İstihbari olarak durumu tespit eden Hz. Peygamber, kendilerine süre tanımış ve neticede sürgün kararı vermiştir. Geriye kalan malları ise ganimet sayılmıştır. Bu ganimetlerden Allah yolunda hicret eden fakir muhacirlere özel bir pay ayrılması (Vâkıdî, 1989b, s. 382) konumuz açısından önem arz etmektedir.

Hicret kavramının "fi sebîlillah" ile bağlantılı olduğu bir diğer hadise ise Hz. Ebû Bekir'in İfk olayındaki rolü nedeniyle Mistah'a yardımı kesmeye yemin etmesidir. Kur'an, Allah yolunda yurtlarını terk edip hicret etmiş (muhacir) kişilere yardım edilmesini istemiş, ne sebeple olursa olsun onlardan dara ve sıkıntıya düşenlere yardımın kesilmesini hoş karşılamamıştır. Onların hatalarının bağışlanması ve affedilmesinin ilahi bağışlanmaya vesile olacağı bildirilmiştir (Kur'an-1 Kerim 24/22). Bu ayetin arka planı ilk dönem siyer kitaplarında yerini almıştır. Hz. Ebû Bekir, kendisine maddi manevi yardımda bulunduğu halasının oğlu Mıstah'ın İfk olayında iftiracılardan birisi olduğunu öğrendiğinde çok üzülmüş, (Vâkıdî, 1989b, s. 434; İbn Hişâm, 1992c, s. 237) kızı Aişe'ye iftira eden Mıstâh'a bundan sonra yardım etmeyeceğine dair yemin etmiştir ( İbn Hişâm, 1992c, s. 237; Halebî, 2008c, s. 221). Yardımsız kalan Mistah'ın maddi zorluklar çektiği anlaşılmaktadır. Kur'an, dedikodulardan rencide olan Hz. Ebû Bekir ailesinden, bu olayda hatalı davrananları bağışlamalarını istemiş, bu örnek davranışın aynı zamanda ilâhî affa vesile olacağını belirtmiştir (Yaşaroğlu, 2007, s. 247). Nur suresi 22. ayet nazil olunca Hz. Ebû Bekir, Allah'ın bağışlamasını tercih ettiğini belirterek yeminini bozup yardıma devam kararı almıştır ( İbn Hişâm, 1992c, s. 238; Taberî, 1967a, s. 617) Bu ayetle Kur'an, aynı zamanda ifk hadisesi kaynaklı toplumda meydana gelen bir husumeti de ortadan kaldırmıştır.

\section{3. Cihad ve Kital}

"Fî sebîlillah" tabirinin siyer kaynaklarındaki en yaygın kullanımı, Hz. Peygamber'in risâlet mücadelesinde kendisine karşı savaş durumu oluşturacak davranışlar sergileyenlerle ilişkilerinde söz konusu olmuştur. Allah Resulü’nün gazve ve seriyyelerinin süreçleri şeklinde ifade edebileceğimiz bu bağlamlar, cihad, kıtal, katl, sefer, darb ve nefr fî sebîlillah kalıplarıyla kaynaklarda yer almıştır.

Cihad kavramının fî̀ sebîlillah tabiri ile kullanımı, cihadın anlam çerçevesini ortaya koymaktadır. Buradan Allah'ın razı olacağı çabaların ifade edildiği söylenebilmekle birlikte (Özel, 1993, s. 531-534), siyerdeki kullanımı çoğunlukla gazve ve seriyyeler ile ilişkilidir. Kur'an'da on üç yerde cihad kavramı fî sebîlillah tabiri ile kullanılmıştır (Kur'an-1 Kerim 2/218; 5/35, 54; 9/19, 20, 24, 41; 49/15; 61/11). Üç yerde ise Allah lafzı yerine ona delalet eden zamir (في سبيلي , في سبيله) kullanılmıştır (Kur'an-1 Kerim 9/24; 5/35; 60/1).

Konuyla ilgili ayetler genelde müminlerin cihad için taltif ve teşvik edilmesi mahiyetine sahiptir (Kur'an-1 Kerim 2/218). İman (Kur'an-1 Kerim 9/20), din, itaat ve amel (Kur'an-1 Kerim 9/41; 61/11) gibi konular da bu çerçeveye dâhil edilmiştir. Cihadın fî sebîlillah tabiri ile kullanıldığı ayetlerde, mümin olmanın gereği (Kur'an-1 Kerim 49/15), cihad ile mescit hizmetlerinin karşılaştırılması (Kur'an-1 Kerim 9/19), din uğrunda cihadın gerekliliği, cihad edenle etmeyenlerin mukayesesi ve mücahitlerin üstünlüğü (Kur'an-1 Kerim 4/95) işlenmiştir. İman edip Allah rızası için birbirlerine yardım edenlerin gerçek müminler oldukları (Kur'an-1 Kerim 8/74), Allah için cihada katılan ve katılmayanların durumu (Kur'an-1 Kerim 9/81) ile imandan sonra hicret ve cihad edenlerin birbirlerinin yardımcıları olmalarının önemi gibi (Kur'an-1 Kerim 8/72) konular da cihad fî sebîlillah bağlamında zikredilmiştir. 
Cihadın her türünün maddi manevi birçok sıkıntısı vardır. Kur'an, cihada çağnıldığında hiçbir bahane üretilmeden mal ve canla bu çağrıya karşılık verilmesini istemektedir (Kur'an-1 Kerim 9/41, 81). Bu konuların işlendiği Tevbe 41. ve 81. ayetler siyer kaynaklarında, Tebuk seferi ile ilişkilendirilmiştir (Vâkıdî, 1989c, s. 990; İbn Hişâm, 1992d, s. 125-126). Hz. Peygamber, bölgeye bir sefer düzenlemeye karar vermiş ve Müslümanların malları ve canlarıyla bu sefere katılmalarını talep etmişti. Mevsim sıcak, kuraklık ve kıtlık olması nedeniyle savaşa hazırlık için şartlar ağırdı (Vâkıdî, 1989c, s. 990; İ̉n Hişâm, 1992d, s. 125-126). Bu durumu firsat bilen münafikların propaganda yaparak hazırlıkları engellemeye çalıştıkları bir sırada Tevbe suresi 41. ayet (Vâkı̂î, 1989c, s. 1022-1023) ve 81. ayetler (İbn Hişâm, 1992d, s. 126) inmiş ve içine şüphe düşerek hazırlıkta yavaş davranan Müslümanlar uyarılmışıtır. Kur'an'ın uyarısı üzerine ashab, bu tür nifaklara aldırış etmeden Hz. Peygamber'in çağrısına samimi bir şekilde icabet edip hazırlanan orduya büyük bir askeri ve malî destekte bulunmuşlardır (Vâkıdî, 1989c, s. 991; İbn Hişâm, 1992d, s. 126-127).

Kur'an'da geçen "cihad fi sebîlillâh" kavramının siyerle ilişkilendirildiği ayetlerden biri de Tevbe 19. ayettir. Kâbe'ye hizmet etme noktasında yaşanan üstünlük tartışmasına Kur'an taraf olmuş, müşriklerin "Biz Harem ehliyiz, haccın su içirenleriyiz ve işte bu Kâbe'nin tamircileriyiz. O halde bizden daha faziletli hiç kimse yoktur" (İbn Hişâm, 1992c, s. 147) iddiaları üzerine "Hacılara su verme ve Mescid-i Harâm'ın imar ve bakım işini (üstlenen kimseyi), Allah'a ve ahiret gününe inanıp Allah yolunda cihad eden kimseyle bir mi tutuyorsunuz? Bunlar Allah katında bir değildirler. Allah zalimler topluluğunu hidayete erdirmez" (Kur'an-1 Kerim 9/19) şeklinde, din uğrunda cihad edenle iman etmeden Kâbe'ye hizmet etmek arasındaki mukayesede cihad edenin üstünlügü vurgulanmıştır. Aynı durum Tevbe 20. ayetle pekiştirilmiştir. Bu ve bundan önceki ayetlerde (Kur'an-1 Kerim 9/17-18) Kur'an, sağlam bir inançla temellendirilmemiş davranışların, dini bir içeriği olsa bile Allah katında bir kıymetinin olmadığını belirterek tartışmaya son noktayı koymuştur. $\mathrm{Bu}$ durumun daha iyi kavranabilmesi için siyer ve tarihle bağlantı kurularak somut bir uygulamaya yer verilmiş, o dönemdeki muhatapların yakinen bildikleri ve dine hizmet noktasında sembol olan Kâbe ile ilgili bazı görevlere referanslar yapılmıştır.

Cihad ile bağlantılı öne çıkan kavramlardan bir diğeri de "kıtal"dir. Kıtal, cihadın fiili savaşa taalluk eden kısmını ifade eder (Mustafa vd., 1992, s. 715; Akalın vd., 2005, s. 1169; Yaman, 2009, s.189; Ünsal, 2020, s.264). Kur'an'da "fî̀ sebîlillah" tabiri ile kıtal kavramı birlikte on iki ayette geçmiştir (Kur'an-1 Kerim 2/190; 3/13; 4/74; 9/111; 73/20). Bu ayetlerde kıtali meşru kılan bir çerçeve vardır. Buna göre saldırganlara karşı haddi aşmamak kaydıyla mukabele etmek gerekir (Kur'an-1 Kerim 2/190). Bunun dışındaki ayetler, meşruiyeti pekiştiren ve teşvik eden özelliktedir (Kur'an-1 Kerim 2/244, 246, 251; 3/13, 167; 4/74-76, 84; 9/111).

Kıtal (savaş), insanların inançlarına bağlılı̆̆ını ortaya koymada ağır bir imtihandır. Kur'an, İslam öncesi döneme ait tarihi referanslarla insanların çoğunun bu sınavı başarıyla geçemediğini belirtmektedir. (Kur'an-1 Kerim 2/246). Hz. Musa'dan sonra, İsrail oğullarının ileri gelenleri, o zamanki peygamberlerden, Allah yolunda savaşmak üzere, kendilerine bir hükümdar görevlendirmesini talep etmişlerdi. Peygamberler'i, "Ya size savaş farz kılınır da savaşmazsanız?!" diye uyardığında, "Yurtlarımızdan çıkartılmış, çocuklarımızdan ayrı düşürülmüşsen, Allah yolunda ne diye savaşmayacak mışız?" sözleriyle isteklerinde kararlı bir görüntü vermişlerdi. Savaş gerçeği ortaya çıkıp Allah savaşı emrettiğinde ise çok azı dışında hepsi kaçmışlardı (Kur'an-1 Kerim 2/246; Taberî, 1967a, s. 468). Aynı durum Kur'an'ın nazil olduğu dönemde de yaşanmıştır. İslamın ilk yıllarında Mekke'de, hicretten hemen sonra da Medine'de Hz. Peygamber'e gelerek sürekli bir şekilde "izin ver savaşalım" diyen bazı kişiler, savaş farz kılınıp emredildiğinde korkuya kapılıp "Rabbimiz! Bize savaşı niçin farz kıldın, bizi yakın bir süreye kadar geri bıraksan olmaz mıydı?" diye kalplerindeki samimiyetsizliği açığa vurmuşlardır. (Kur’an-1 Kerim 4/77)

Kur'an'da, Müslümanların mücadelesinin ulvi değerler üzerine olduğu, düşmanın ise azgınlık ve taşkınlık şeklinde tanımlanabilecek tağut uğruna olduğu tespiti yapılmıştır (Kur'an-1 
Kerim 4/76). Ayrıca iman ve şirk uğrunda savaşan iki gurubun mukayesesi yapılmış (Kur'an-1 Kerim 3/13), düşmanın başka özelliklerine de atıfta bulunularak savaşa dair meşruiyet zemini

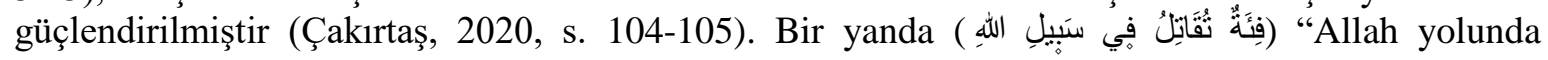
çarpışanlar" yani mücadelesi meşru bir zeminde olan bir grup, diğer tarafta ise Allah'a karşı bile bile nankörlük edenler vardır. Bu konuların işlendiği Âl-i İmrân 13. ayet siyer kaynaklarında Benî Kaynuka Yahudileri ile iliş̧kilendirilmiştir (İbn İshak, 1978, 313-314; İbn Hişâm, 1992c, s. 147; Halebî, 2008a, s. 343). İlk dönem siyer kaynaklarında yer alan bilgilere göre, Benî Kaynuka Yahudileri ile Hz. Peygamber arasında geçen bir konuşma üzerine bu ayet nazil olmuştur. Hz. Peygamber, Kureyş'in başına gelenler kendilerinin de başına gelmeden iman etmelerini istediğinde, "sen savaş bilmeyen kişilerle savaştın, biz onlara benzemeyiz" şeklinde meydan okumaları üzerine Kur'an, Bedir'de yaşananları hatırlatarak bundan sonra kendi başlarına gelebilecekler konusunda uyarıda bulunmuştur (İbn İshak, 1978, 313-314; İbn Hişâm, 1992c, s. 40; İbn Hişâm, 1992b, s. 148). Ayet, geç dönem siyer kaynaklarında da yine Bedir savaşıyla ilişkilendirilmiştir (Halebî, 2008b, s. 217).

Kur'an "kıtal fi sebîlillâh" kavramı çerçevesinde savaşla ilgili ilahi kanunlarını hatırlatmaktadır. Âl-i İmrân suresi 166 ve 167 ayetlerde belirtilen sebep-sonuç bağlamındaki yasalar gereği, savaşta tedbirli, hazırlıklı ve kararlı olanlar başarılı olmaktadır. Birlik içinde olmayan, samimiyet problemleri yaşayan ve savaşta sebat göstermeyenler yenilmeye mahkûmdur. Siyer kaynaklarının Uhud savaşı ile ilişkilendirdiği (Vâkıdî, 1989a, s. 325; İbn Hişâm, 1992c, s. 93) bu ayetlerde Kur'an, savaşın kaybedilmesinin nedeninin, ilahi yasalara göre hareket edilmemesi ve münafıkların ortaya çıkarılması olduğunu bildirmektedir. Bu ayetin konusu siyere aynen yansımıştır. Abdullah b. Ubey ve arkadaşları, Hz. Peygamber ile birlikte müşriklere karşı çarpışmak üzere Uhud savaşı için yola çıkmışlar, ancak savaş öncesi çeşitli mülahazalarla yoldan geri dönüp Müslümanları terk etmişlerdi. Bu durum karşısında, savaşmak istemiyorlarsa hiç değilse savunmada kalıp geri dönmemeleri için ikna edilmeye çalışıldıklarında ise "savaş olacağını bilsek sizinle geliriz" diye cevap vermişlerdir (Vâkıdî, 1989a, s. 325; İbn Hişâm, 1992c, s. 93).

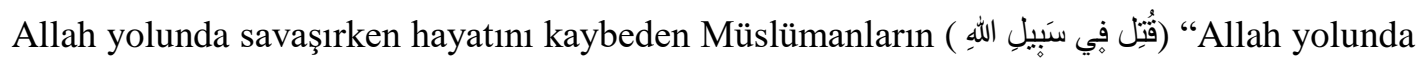
öldürülenler" olarak tanımlanması, fî̀ sebîlillah kavramının bir başka kullanımıdır. Kur'an'da dört ayette geçmektedir. Bu meyandaki ayetlerin temel mesaj1 ise Allah yolunda öldürülenlerin (şehitliğin) kıymeti ve mükâfatları üzerinedir (Kur'an-1 Kerim 2/154; 3/157, 169; 47/4). İlk dönem siyer kaynaklarında Âl-i İmrân suresinin 157. ve 169. ayetlerinin arka planıyla siyer arasında bağlantı kurulmuştur. İbn Hişam'ın bildirdiğine göre bu ayetler, Uhud savaşında inen altmış ayetin içerisinde yer almaktadır. (İbn Hişâm, 1992c, s.191). Bu ayetlerin, savaşın seyrinde yaşanan sıkıntılı anlarda Hz. Peygamber tarafından dağılma eğilimindeki Müslümanları toparlamak ve savaşa teşvik etmek için nazil olduğu düşünülebilir. İbn Hişam, Âl-i İmrân 157. ayeti kendinden önceki ayetlerle birlikte, "Allah yolunda ölümden korkanlardan olmaktan Allah'ın sakındırması" başlığ 1 altında topladığı ayetlerle birlikte vermiştir. Burada, Allah yolunda ölmekten korkmamak gerektiği belirtilmiştir. İbn Hişam ayetin tefsirinde, "ölüm elbette olacaktır, ondan kurtuluş yoktur, o halde Allah yolunda ölüm veya katl olunma daha hayırlıdır" ifadelerini kullanmıştır (İbn Hişâm, 1992c, s. 191). Siyer kaynaklarında Âl-i İmrân 169. ayet, cihada terğib ve teşvik bağlamında zikredilmiştir (İbn Hişâm, 1992c, s. 193; Diyârbekrî, b.t.a, 443; Halebî, 2008b, 341). "Allah yolunda öldürülenleri sakın ölüler sanma! Bilâkis onlar diridirler" (Kur'an-1 Kerim 3/169). Bu ayette de "Allah yolunda öldürülme"nin bir yok oluş olmadığı, aksine ebedi diri kalmak olduğu vurgulanarak Müslümanlar savaşa teşvik edilmiştir. Bu ayetler, Uhud savaşında mağlubiyetin ve kaybedilen canların sebep olduğu psikolojik çöküntüye ve Mekkeli müşriklerin olumsuz propagandalarına karşı ciddi bir destek olmalıdır. Bu ayetlerle şehitlerin durumlarının açıklığa kavuşturulması ve onlara verilen kıymetin ortaya konması, aynı zamanda savaşta yakınlarını kaybedenlerin ve Müslümanların moral ve motivasyonlarına ciddi bir katkı sağlamış olduğu muhakkaktır. 
Allah yolunda savaş için yola çıkmanın süreçlerini ifade ederken, fî̀ sebîlillah kavramıyla birlikte kital'den başka “darb” (ضَرب في سَبَيلِ اللهِ) (Kur'an-1 Kerim 4/94) ve “nefr” (نفر في سبيل الله) (Kur'an-1 Kerim 9/38; Çetinkaya, 2019, s. 124) kelimeleri de kullanılmıştır. Kur'an'da, Allah yolunda savaşırken her türlü ihtimalin göz önünde bulundurularak hareket edilmesi gerektiğine dikkat çekilmektedir (Kur'an-1 Kerim 4/94). Savaşa veya sefere çıkarken gerekli araştırmanın yapılması, seferde bile olsa yanlış ve eksiksiz bilgi ile haksız yere bir kimsenin öldürülmesinin asla câiz olmayacağı belirtilmiştir. Bu durum Kur'an'da "darb fi sebîlillah" kullanımının geçtiği ayetle izah edilmiştir. "Darb fi sebîlillah", Allah yolunda sefere çıkmak ve Allah yoluna koyulmak anlamlarında Kur'an'da bir yerde, Nisa suresi 94. ayette geçmiştir. Konu yine cihad bağlamında ele alınmıştır.

Söz konusu ayet ve ayetin konusu olan olay, erken dönem siyer kaynaklarında da yer almıştır. İbn Hişam, Mekke'nin fethinden önce gerçekleşen bu olayla ilgili detaylı bilgi vermiştir (İbn Hişâm, 1992c, s. 191). İbn Ebi Hadred ve arkadaşları çıktıkları bir seriyyede/seferde, karşılaştıklarında müminlerin selamlama tarzı ile selam veren Âmir b. el-Ezbat el-Eşcai'yi öldürmüşler, bineğine ve yanında bulunanlara el koyup Medine'ye dönmüşlerdi (Vâkıdî, 1989b, s. 797; İbn Hişâm, 1992d, s. 206; Taberi, 1967b, s. 36). Olayı öğrenen Hz. Peygamber bu durumu onaylamamış, üzüntüsünü dile getirerek "Kalbini mi yardın, nereden biliyorsun?" (Diyârbekrî, b.t.b, s. 67-68; Halebî, 2008c, 341) diyerek öldüren sahabiye çıkışmıştı. İbn Hişam'ın bildirdiğine göre Nisa suresi 94. ayet bu olayı açıklığa kavuşturmak üzerine inmiştir. Kur'an, din uğruna savaşa çıkıldığında iyi bir istihbarat çalışması yapılmadan, kendisini Müslüman olarak tanıtan bir kişinin, dünya hayatının geçici menfaatlerine göz dikerek öldürülmesini hoş karşılamamıştır (İbn Hişâm, 1992d, s. 206-207).

Kur'an, savaş ilan edildiğinde veya bir sefer için çağrıda bulunulduğunda, müminleri malları, canları ve ellerindeki bütün imkânlarıyla seferber olmalarını istemektedir. Gerekli gayreti göstermeyip seferber olmayanlar şiddetle eleştirilmiştir (Kur'an-1 Kerim 9/38). Bu durum Kur'an'da, "nefr fi sebîlillah" (نفر في سبيل الله kavramının geçtiği ayetle ifade edilmiştir. "Nefr fi sebîlillah", Allah yolunda sefere çıkmak, Allah yolunda seferber olmak anlamlarında Kur'an'da bir yerde, Tevbe suresi 38. ayette geçmektedir. Siyer kaynaklarında bu ayet, daha önce zikredilen Tevbe 41. ve 81. ayetler (Vâkıdî, 1989c, s. 1022-1023; İbn Hişâm, 1992d, s. 126) ile aynı şekilde Tebuk seferi ile ilişkilendirilmiştir (İbn Hişâm, 1992d, s.148-149). Hasat döneminin başladığı, kuraklık ve kıtlığın baş gösterdiği sıcak bir zamanda Medine'den uzak bir bölgeye, büyük bir güce karşı savaş için seferberlik ilan edildiğinde Müslümanlar şartların zorluğu ve münafikların da etkisiyle yavaş davranmışlardı (Vâkıdî, 1989c, s. 1022, 1060; İbn Hişâm, 1992d, s. 148). Bu durum karşısında Kur'an sessiz kalmamış, "Ey iman edenler! Size ne oldu ki, "Allah yolunda seferber olun" denilince yerinize çakılıp kaldınız; yoksa ahiretten vazgeçip de dünya hayatıyla yetinmeye razı mı oldunuz? Hâlbuki dünya hayatının sağladığı fayda ahiretinkine göre pek azdır" ifadeleriyle (Kur'an-1 Kerim 9/38) Müslümanları, içine düştükleri durumdan dolayı kınamıştır. İbn Hişam, burada olay ve ayetleri bir araya getirmeye, siyeri Kur'an'la anlatmaya devam etmektedir. Ona göre Kur'an, sadece bu ayette kınayıp kalmamış, sonraki iki ayetle de muhatapları tehdit etmiştir. Müminler, Hz. Peygamber'in çağrısına uymayıp sefere çıkmamaları durumunda şiddetli bir azapla karşılaşmak ve yerlerine başka bir millet getirmekle uyarılmışlardır (Kur'an-1 Kerim 9/39). Ayrıca Hz. Peygamber'e yardım etmeseler de bunun bir kıymeti yoktur, zira Allah, inkâr edenler onu Mekke'den çıkardığında mağaradaki iki kişiden biri olarak nasıl yardımsız bırakmadıysa burada da yardımsız bırakmayacaktır (Kur'an-1 Kerim 9/40). Nitekim Müslümanlar, Kur'an'ın bu tehdit ve uyarıları üzerine Hz. Peygamber'in çağrısına samimi bir şekilde icabet etmişlerdir (Vâkıdî, 1989c, s. 991; İbn Hişâm, 1992d, s. 126-127).

"Fî sebîlillah" kavramının Kur'an'da cihad, kıtal, darb ve nefr kelimeleriyle kullanımlarının yanında müstakil olarak fî sebîlillah kullanımı da vardır. Kur'an'da zekâtın verileceği yerler 
sayılırken "Allah yolunda olanlar" (Kur'an-1 Kerim 9/60) da bunlardan biri olarak sayılmıştır. Bu kullanım genel bir özellik arz etse de ayetin mücahitlere matuf olduğu ortadadır. (Köse, 2004, s. 110; Aktaş, 2015, s. 67-86). Benzer bir kullanım, Hz. Ali'nin bir gazve sırasında olanlardan dolayı şikâyet edilmesi hadisesinde de geçmiştir (İbn Hişâm, 1992b, s. 603).

Gazve ve seriyyeler bağlamında "fî̀ sebîlillah" kavramının siyerde geniş bir karşıllk bulduğunu görmek mümkündür. Medine Vesikası'nın tesisinden itibaren Medine dönemi boyunca birçok hadisede bu kavramın kullanıldığı görülmektedir. "Cihad fî sebîlillah" kavramının, Abdullah b. Cahş seriyyesinde hicretle (Kur'an-1 Kerim 2/218; İbn Hişâm, 1992a, s. 605), Uhud Gazvesi'nde kıtal, musibet ve ölüm korkusu ile (Kur'an-1 Kerim 3/146-147, 156-158, 165-171; İbn Hişâm, 1992b, s. 112, 116, 120) ilişkilendirildiği anlaşılmaktadır. Hz. Ebû Bekir'in Hicri 9. y1lda Hac emiri olarak gönderildiğinde müşriklerin Kâbe hizmetlerini bir övünç vesilesi yapmaları üzerine, Allah yolunda cihad etmenin Mescid-i Haram'a yapılan hizmetten daha kıymetli olduğuna işaret etmek için kullanıldığ1 görülmektedir. (Kur'an-1 Kerim 9/18-19; İbn Hişâm, 1992b, s. 547).

"Fî sebîlillah" kavramının kıtal kelimesiyle birlikte kullanımının siyerdeki diğer yansımalarına ise Medine Vesikas1, Bedir Gazvesi (Kur'an-1 Kerim 3/12-13; 8/45-47, 57, 60, 61; İbn Hişâm, 1992a, s. 74) ve Benî Kaynuka Yahudilerinin kuşatılması (İbn Hişâm, 1992a, s. 552) olaylarında rastlanmaktadır. Medine Vesikası'nda bir müminin savaşta diğer müminlerin aleyhine olacak şekilde kendi başına anlaşma yapamayacağı ifade edilirken Allah yolunda kıtal ile birlikte "nale fî sebîlillah" (نال دماءهم في سبيل الله kalıbı tercih edilmiştir (İbn Hişâm, 1992a, s. 503). Siyerde, kıtale giden süreçleri ifade eden farklı kavramlar da kullanılmıştır. Taif'te "sâri"” (سار فارع (İbn Hişâm, 1992b, 498), Tebük seferinde "neşît" (نشيط) (İbn Hişâm, 1992b, s. 529) ve Dumetu'l-Cendel'de "gazve fî sebîlillah" (İbn Hişâm, 1992b, s. 632) tabirleri yer almıştır. Son olarak da Mûte harbinde zor şartlarda Medine'ye dönen askerler halk tarafından kınanırken "Ya ferrar fî sebîlillah" ifadeleriyle savaştan kaçmakla suçlanmışlardır (İbn Hişâm, 1992b, s. 382).

\section{4. İnfak}

"Fî sebîlillah" kavramının yer aldığı son başlık “infak fî sebîlillah” şeklindedir. Kur'an'da yedi ayette geçmiştir (Kur'an-1 Kerim 2/195, 261, 262; 8/60; 47/38; 57/10; 9/34). Ayetlerde infak kavramı cihad, itaat ve din gibi değişik alanlarda kullanılmıştır. İnfak usulü (Kur'an-1 Kerim 2/195, 262), infak yapmaya teşvik (Kur'an-1 Kerim 47/3) ve infak yapanların mükâfatı, bu bağlamda zikredilmiştir (Kur'an-1 Kerim 2/261; 8/60; 9/34; 57/10).

"İnfak fî̀ sebîlillah", gazve ve seriyye giderlerinin karşılanmasında önemli bir yer edinmiştir. Müminlerden bu tür faaliyetlerdeki gerekli ihtiyaçların karşılanması için fedakârlıkta bulunmaları talep edilmiştir (Kur'an-1 Kerim 2/195). Bu ayetlerde, müminlerin sahip olduklarından Allah yolunda harcama yapmaları istenmiş (Kur'an-1 Kerim 2/195; 57/10; 9/34), ellerini sıkı tutanlar şiddetle eleştirilmiştir (Kur'an-1 Kerim 9/34). İnfak edenlerin yedi başaklı ve her başağında yüz dane olan ekine benzetilmesi de teyiden zikredilmiştir (Kur'an-1 Kerim 2/261). Ayrıca, siyer kaynaklarına da yansiyan Tevbe suresi 34. ayetle iki ehli kitap örnek verilerek, mal biriktirip de Allah yolunda harcamayanların akıbetlerinin can yakıcı bir azap olduğu belirtilmiştir (Kur'an-1 Kerim 9/34; İbn Hişâm, 1992d, s. 148).

İbn Hişam, Enfâl suresi 60. ayeti, Bedir savaşından hemen sonra inen ayetler içinde saymış ve "Müslümanlara ögüt, nasihat ve onlara harp yollarını öğretme hakkında nâzil olan âyetler" başlığı altında zikretmiştir (İbn Hişâm, 1992b, s. 238). Tarihi süreç içerisinde, Bedir'de yenilen Mekkeli müşrik ekâbirin boş durmadıkları, intikam için yeni bir savaş hazırlıklarına hemen başladıkları malumdur. Bedir ve müşrikler örneğinde olduğu gibi Müslümanların da her an muhtemel bir savaşa karşı hazırlıklı olmaları istenmiştir. Bu ayette "infak fi sebîlillâh" kavramıyla tam da bu hazırlıklar için yapılan harcamaların (Allah yolunda infak) önemi ve kıymeti ortaya konarak, Müslümanlar 
teşvik edilmiş ve bu tür harcamaların Allah indinde karşılıksız kalmayacağı vurgulanmıştır. (Vâkıdî, 1989b, s. 732)

"İnfak fî̀ sebîlillah" kavramının siyer kaynaklarına yansımalarından biri de kaza umresi olarak bilinen Umretü'l-Kazâ ile alakalıdır. Umretü'l-Kazâ'ya katılmak için maddi imkânı olmayan müminlere yardım edilmesi istenmiştir (Vâkıdî, 1989b, s. 732). Hz. Peygamber, durumu iyi olanların bu konuda infakta bulunması çağrısında bulunmuştur. Bu hususta Kur'an da devreye girmiş (Kur'an1 Kerim 2/195), bu tür ihtiyaçları karşılamayı Allah yolunda infak kabul ederek durumu iyi olanların umre ihtiyaçlarını karşılayamayanlara yardımcı olmalarını istemiş, bunun aynı zamanda ahirette karşılığının olacağını belirterek yardım kampanyasına teşvik etmiştir (Vâkıdî, 1989b, s. 732).

Allah yolunda infakın siyere yansımaları bağlamında, Halid b. Velid'in Benî Cezîme seferine (İbn Hişâm, 1992b, s. 431) ve kimi bedevi münafikların infaklarını başa kakmalarına (Tevbe, 998/99; İbn Hişâm, 1992b, s. 553) da işaret edilebilir. Nitekim Halid b. Velid ile Abdurrahman b. Avf arasında, Halid b. Velid'in söz konusu seferdeki yaptıkları nedeniyle yaşanan sorun karşısında Allah Resulü, Halid'i ikaz etmiş ve "nice altını Allah yolunda infak etse" yine de Abdurrahman'ın mertebesine erişemeyeceğini belirtmiştir.

حصر في ( Kur'an'da, infak fî̀ sebîlillah tabirinin anlam olarak benzer bir kullanımı da "hasr" (سَبيلِ الله kelimesi ile yer almıştır. Bakara 273. ayetteki bu ifade ile kendisini Allah yoluna adayanlar için her tür infakta bulunulmasının gereğine işaret edilmiştir. Ayetin anlam içeriği siyerde, Suffe ehli ile de irtibatlandırılmıştır (İbn Habib, 1996, s. 85).

\section{Sonuç}

Kur'an'ın temel kavramlarından biri olan “fî̀ sebîlillâh” tabirinin Kur'an'da geniş bir kullanım alanına sahip olduğu anlaşılmaktadır. "Fî sebîlillâh" ifadesinin geçtiği ayetlerin tamamı Medine dönemi ile ilişkilendirilmiştir. İfadenin geçtiği ayetlerde din, iman, itaat, amel, hicret, cihad, infak, şehitlik ve ahlak gibi İslam dininin ana konuları yer almıştır. "Fi sebîlillah" ifadesi kimi zaman müstakil bir kavram şeklinde ama çoğunlukla da bir kavramın mahiyetini izah eden sıfat olarak kullanılmıştır.

"Fî sebîlillah" kavramı on bir farklı kelimeyle birlikte kullanılmıştır. Kavram, yer aldığı ayetlerin anlamlarına istikamet vermiştir. Allah yolunda hicret, Allah yolunda cihad ve Allah yolunda kıtal en fazla kullanılanlardır. Bunlar1, Allah yolunda öldürülme, Allah yolunda infak ve Allah yolunda bir şeye maruz kalma takip etmektedir. Allah yolunda sefere çıkma, Allah yolunda seferber olma, Allah yolunda, Allah yoluna adanma ve Allah yolunda eziyet görme ise Kur'an'da birer ayette yer almıştır.

"Fî sebîlillâh" ifadesinin Kur'an'daki kullanımları kısmen de olsa siyer kaynaklarına yansımıştır. Tarihte ve siyerde geçen birçok olay, kavramın geçtiği ayetlerle ilişkilendirilmiştir. İlk dönem İslam tarihçilerinin ve siyercilerin eserlerine aldığı bu yansımalar, ayetlerin anlaşılmasına büyük etki etmiştir. Aynı tespitin müfessirler için de geçerli olduğu söylenebilir.

"Fi sebîlillâh" tabiri, Hz. Peygmaber ve müminlerin, tevhid mücadelesinin aşamalarının her birinde tanımlanan basamakların sıfatı olarak gelmiştir. Mekke döneminde çekilen eziyetler, uğranılan musibetler, hicret, cihad, kıtal ve infak, "fi sebîlillâh" ifadesiyle değerli kılınmış ve teşvik edilmiştir. Bu kavramların siyerde onlarca karşılığ oluşmuştur. Özellikle Medine dönemi bu meyanda belirgin durumdadır. Müslümanların hicreti, seriyyeler ve gazveler bu kavram üzerinde müminlere teselli ve teşvik olmuştur.

Kur'an ve tarih kaynakları arasındaki irtibatın, tarihsel süreçte ilmi çalışmalar sonucunda şekillenmiş olduğu dikkate alındığında bu yöndeki çalışmaların bugün de devam etmesinin gerekliliği ortadadır. 


\section{Kaynaklar}

Acar, C. (2014a). Risalet dönemi savaşlarının başlamasında Mekke döneminde müslümanlara yönelik saldırıların rolü. Gaziosmanpaşa Üniversitesi Illahiyat Fakültesi Dergisi, 2, 43-68.

Acar, C. (2014b). Anahatlarıyla cahiliye toplumunda savaş sebepleri $=$ An outline of the reasons for war in the jahiliyyah society. Ilahiyat Araştırmaları Dergisi = Journal of Divinity Studies, 1 , 93-114.

Aktaş, B. (2015). Tevbe suresi 60. ayet bağlamında zekâtın sarf yerleri. Diyanet İlmi Dergi, 2, 6786.

Albayrak, H. (2013). Zekât verilecek yerler bağlamında fî sebîlillah, [Yayımlanmamış yüksek lisans tezi]. Recep Tayyip Erdoğan Üniversitesi Sosyal Bilimler Enstitüsü

Çakan, İ. L. (1988). Abdullah b. Cahş. Türkiye Diyanet Vakfi İslâm Ansiklopedisi içinde (Cilt. 1, ss. 88-90). TDV Yayınları.

Çakırtaş, M. (2020). The term qatl in the Qur' ān as a source of history and its historical framework, ULUM, 3(1), 93-110.

Çetinkaya, Ş. (2019). Cihâd ve kıtâl ayetlerinde te'kîd, Düzce Üniversitesi İlahiyat Fakültesi Dergisi, $3(2), 121-140$.

Dinçoğlu, H. (2015). Kur'an'da "sebîlullah” kavramı, [Yayımlanmamış yüksek lisans tezi]. Necmettin Erbakan Üniversitesi Sosyal Bilimler Enstitüsü

Diyârbekrî, K. H. b. M. (b.t.). Târîhu'l-hamîs fì ahvâli enfesi nefîs: Cilt. 2. Daru's-Sadır.

Elik, H. (2006). el-Kital fî̀ sebîlillah ve tedaiyatuhu ke şea'irin islamiyyin. M. Ü. İlahiyat Fakültesi Dergisi, 31(2), 119-132.

Fîrûzâbâdî, M. M. b. Y. (1991). el-Kâmûsü'l-Muhît. Dâru İhyai't-Türasi'l-Arabî.

Halebî, E. F. N. A. b. İ. (2008a). İnsânü'l- 'uyûn fì sîreti'l-emîni'l-me'mûn: Cilt. 1. Darü'l-Kütübi'lİlmiyye.

Halebî, E. F. N. A. b. İ. (2008b). İnsânü'l- 'uyûn fî sîreti'l-emîni'l-me 'mûn: Cilt. 2. Darü'l-Kütübi'lİlmiyye.

Halebî, E. F. N. A. b. İ. (2008c). İnsânü'l- 'uyûn fì sîreti'l-emîni 'l-me'mûn: Cilt. 3. Darü'1-Kütübi'lİlmiyye.

İbn Habib, E. M. B. H b. Ö. (1996). el-Muktefâ min sîreti'l-Muștafâ. Daru'l-Hadis.

İbn İshak, M. b. İ. b. Y. (1978). Siretü İbn İshak. Daru'l-Fikr.

İbn-i Manzûr, E. F. C. M. b. M. (1999). Lisânu'l-'Arab. Dâru İhyâi't-Turâsi'l-Arabî.

İbn Hişâm, E. M. C. A. b. H. (1992a). es-Sîretü’n-nebeviyye: Cilt. 1. Daru'l- Hayr.

İbn Hişâm, E. M. C. A. b. H. (1992b). es-Sîretü'n-nebeviyye: Cilt. 2. Daru'l- Hayr.

İbn Hişâm, E. M. C. A. b. H. (1992c). es-Sîretü’n-nebeviyye : Cilt. 3. Daru'1- Hayr.

İbn Hişâm, E. M. C. A. b. H. (1992d). es-Sîretü’n-nebeviyye: Cilt. 4. Daru'l- Hayr.

Köse, M. (2004). "Fî sebîlillâh" kavramının zekât açısından tahlili. Atatürk Üniversitesi Illahiyat Fakültesi Dergisi, 21, 107-134.

Mustafa, İ., Zeyyat, A. H. \& Abdulkâdir, H. vd. (1992). el- Mu'cemu'l-vasît. Çağrı Yayınları.

Taberî, E. C. M. b. C. (1967a). Târîhu'l-ümem ve'l-mülûk: Cilt. 2. Darü't-Turas. 
Taberî, E. C. M. b. C. (1967b). Târîhu'l-ümem ve'l-mülûk: Cilt. 3. Darü't-Turas.

Ünsal, H. (2020). İmam Mâtürîdî’nin te'vîlâtü'l-Ḳur'ân'ında cihad ve kitâl ayetlerinin yorumu, Eskiyeni, (40), 259-281. https://doi.org/10.37697/eskiyeni.667743

Özel, A. (1993). Cihad. Türkiye Diyanet Vakfı İslâm Ansiklopedisi içinde (Cilt. 7, ss. 531-534). TDV Yayınlar1.

Vâkıdî, E. A. M. b. Ö. (1989a). Kitabu'l-Megâzi: Cilt. 1. Daru'l-a'lemî.

Vâkıdî, E. A. M. b. Ö. (1989b). Kitabu'l-Megâzi: Cilt. 2. Daru'l-a'lemî.

Vâkıdî, E. A. M. b. Ö. (1989c). Kitabu'l-Megâzi: Cilt. 3. Daru'l-a'lemî.

Yaman, A. (2009). Savaş. Türkiye Diyanet Vakfi İslâm Ansiklopedisi içinde (Cilt. 36, ss. 189-194). TDV Yayınları.

Yaşaroğlu, M. K. (2007). Nur Suresi. Türkiye Diyanet Vakfi İslâm Ansiklopedisi içinde (Cilt. 33, ss. 247-248). TDV Yayınlar1.

Yıldız, İ. (2015). Kur'ân'da sebîlüllah kavramı. Emin Yayınları.

Zemahşerî, C. E. K. M. b. U. (2016). el- Keşşâf: Cilt 1. Kültür Bakanlığı Yayınları. 